\title{
Impact of Climatic Variation on Parasitic Infections - Short Review
}

\author{
Sonu Kumari Agrawal ${ }^{1}$ \\ ${ }^{I}$ Department of Microbiology, All India Institue of Medical Sciences, New Delhi, India
}

*Corresponding Author: Dr. Sonu Kumari Agrawal, Senior resident, Department of Microbiology, All India Institute of Medical Sciences, New Delhi, India

\begin{abstract}
Climate variability have been shown to exert rising cases of parasitic infections in humans. Both natural phenomenon and human interventions can lead to Climate change and environmental disturbances. Through natural condition or human interventions alter the environmental conditions and parasites and their vectors in which they develop and transmit the diseases. Multifactorial conditions such as deforestration, urbanisation, water control projects, bodies of water in disrupted area, globilisation and natural condition (Floods, Earth quake, Tsunami) can singly or in combination can lead to ecological disturbances, survival of parasites, their spread and in turn incidence of parasitic infections. The cited climatic parameter affect breeding and development of specific parasite and host and their transmission pattern of diseases. Therefore, improved surveillance and monitoring is needed so that one should make better use of early warning information to make early action towards epidemic preparedness due to ecological disturbances. The leaders of health sector must stand hand in hand with climate negotiators to confront climate change. Further, leaders from government, private sectors and civil society are encouraged to take action towards climatic change.
\end{abstract}

Keywords: Climate, parasite, Enviornment, Natural condition, Man-made

\section{INTRODUCTION}

Climate is average pattern of variation in Temperature, humidity, atmospheric pressure, wind, precipitation in region over long periods of time. Both natural phenomenon and human interventions can lead to Climate change and environmental disturbances. Climate variability have been shown to exert rising cases of parasitic infections in humans. Only a handful of studies have attempted to predict the effect of climate change on the distribution or transmission.

The First part of article explains about the types of Climatic conditions and changes, implicated in rising incidences of parasitic infections in humans. The second part explains about the emerging parasitic infections due to climatic variability and which constitutes morbidity in human populations.

\section{Climatic Conditions AfFecting Transmission of Parasitic Infections}

Through natural condition or human interventions alter the environmental conditions and parasites and their vectors in which they develop and transmit the diseases. Multifactorial conditions such as deforestration, urbanisation, water control projects, bodies of water in disrupted area, globilisation and natural condition (Floods, Earth quake, Tsunami) can singly or in combination can lead to ecological disturbances, survival of parasites, their spread and in turn incidence of parasitic infections.

\section{Deforestration -}

Deforestration is an important condition that affect vector and their parasites. When the forest is cleared, it is converted in to crop farming, grazing land, settlement of migrant populations or left as open plots can create a favourable ecological niches for new vector/existing vector and their parasites survival and diseases transmission. 
Bodies of water-

Forest soil is acidic in nature and cleared lands with alkaline $\mathrm{pH}$ are prone to formation of puddles with water, which is favourable environment for survival of anophiline larva( 1-3). Conversion from acidic to alkaline $\mathrm{pH}$ due to reduction of water salinity favours the growth of vectors such as snails and transmission of diseases by their parasites(4).

\section{Urbanisation -}

As for settlements humans are migrating from rural to densely populated urban area, which increases the vector and host interaction and transmission of parasitic infections. In addition if anthrophyllic vector is present, migrant population act as reservoir for transmission of zoonotic parasitic infections. Indigenous population have developed immunity to parasites. However, new settlers have not developed immunity and resulting in increased vulnerability to vectors and transmission of diseases.

\section{Water control projects-}

Construction of irrigation canals, dams and reservoirs can lead to change in ecological niches of vector such as mosquitoes, snails and their parasites. These canals provide suitable breeding sites for mosquitoes and transmission of diseases. The habitat of mosquitoes vary with their species. Some mosquitoes prefer moving stream, clean water, reservoirs; other inhabitat costal areas.

\section{Globilisation -}

New roads construction provides acceleration of tourism, construction of irrigation canal, dams and new settlements with all there in singly or combination can lead to environmental disturbances. Due to such construction non- immune population are exposed to indigeneous vector and new settlements lead to introduction of new vector to those areas ( 5-7). Road construction in previously forested area can lead to erosion and formation of bodies of water in disrupted areas. These water bodies then serve as breeding ground for vector (8).

\section{Components of climatic system -}

Interaction among different climatic component such as temperature, humidity, rainfall, precipitation can lead to change in climate and ecological imbalance. In earlier times, natural phenomenon was solely responsible for disturbances in ecological niches but today man made activities are also responsible for climatic change: Forest clearance and land coverage, industrial activities, fuel combustion, stratospheric ozone depletion, freshwater depletion and contamination. These factors in singly or in combination can lead to environmental changes and ecosystem impairment which further lead to diverse health consequences $(9,10)$

\section{Temperature and rainfall -}

Rising global warming causes alteration in hydrological cycle leading to more droughts and floods resulting in poor hygiene, fresh water depletion and contamination leading to adverse health consequences. Heavy rainfall lead to collection of water in water bodies providing breeding site for mosquitoes. Rain provides a favourable environment to vector, which prolongs their life. Transmission of many parasitic diseases found during rainy season $(11,12)$.However, climate change and associated impacts will vary from region to region around the world.

\section{Environmental Changes Affecting Parasitic Disease Transmission}

The above stated climatic parameter affect breeding and development of specific parasite and host and their transmission pattern of diseases. Some of examples of parasitic diseases affected by environmental change has been discussed below-

\section{A. Malaria-}

Malaria is diseases of tropical regions. The Vectors and Parasitic species of malaria changes sharply due to change in ecological niches. The minimum temperature $\left(16-19^{\circ} \mathrm{c}\right)$ and maximum temperature $\left(33-39^{\circ} \mathrm{c}\right)$ with relative humidity $\left(40-80^{\circ} \mathrm{c}\right)$ required for breeding of anophiline vector $(13)$. When a climate is changed, indigenous anophiline vector are not able to survive due to changed ecological niches, it will disappear and replaced by different anophiline species may occupy the area. Enviornmental factors such as climate, deforestation, vegetation, water bodies can lead to increase in transmission of malaria. For example, malaria outbreak have occurred in Western Kenya due to 
average rise in temperature and heavy rainfall, provide breeding site to mosquitoes and prolong their life. Similiarly, in 1987, due to rise in temperature and rainfall was associated with rise in malarial cases at higher altitude. Climatic conditions such as El Nino, Tsunami, Hurricae have been shown to increased transmission of malaria. El Nino affected area such as in parts of East Africa due to heavy rainfall resulted in rise in malarial cases in Southwestern Uganda (14). Tsunami can result in smashed sewer lines, contaminated fresh water supplies, overcrowded refugee camps, create a breeding ground for mosquitoes and precipitate the malarial outbreak. Similarly, Combination of flooding, loss of shelter, and destruction of infrastructure after hurricane provide breeding site for mosquitoes and result in increase transmission of malaria. After deforestation in Malaysia, vegetation of erythrinia tree (bromeliads on their branches), are preferred breeding site for anopheles mosquitoes resulted rise in malaria cases due to A. bellator (15). The prevalence of malaria returned to previous level after removal of bromeliads from those area. Unplanned urabinastion is responsible for intermittent water supply and improper sewage and solid waste disposal provide breeding site for mosquitoes. Construction of hydroelectric dams, irrigation canals in Brazil, Africa, India there was increase in malaria transmission rate (16).

\section{Kala-Azar:}

Kala-Azar is caused by Leishmania species. It is transmitted by sandflies (phlebotomus). The vector and Leishmaniasis infection association due to climatic change is shown in table 1(17-20).

Table 1. Effect of climatic change on Leshmaniasis infection.(17-20)

\begin{tabular}{|l|l|l|}
\hline Area of climatic change & Type of climatic change & $\begin{array}{l}\text { Effect on parasitic infections due to } \\
\text { climatic changes }\end{array}$ \\
\hline Latin America & $\begin{array}{l}\text { Deforestation led to increase in fox } \\
\text { population (reservoir host) }\end{array}$ & Increase in visceral leishmaniasis. \\
\hline In Brazil & $\begin{array}{l}\text { Croping of pines and gmelina after } \\
\text { clearing of land led to increase in spiny rat } \\
\text { (reservoir host) }\end{array}$ & Increase in cutaneous leishmaniasis. \\
\hline Latin America & $\begin{array}{l}\text { Sugar of ripe coffee helps in development } \\
\text { of parasites in vector } \\
\text { (phelbotomine sandflies) in coffee growing } \\
\text { regions }\end{array}$ & Increase in leishmaniasis cases. \\
\hline In Southern Sudan & $\begin{array}{l}\text { Globalisation (migrants from endemic } \\
\text { regions) }\end{array}$ & Increase in leishmaniasis cases. \\
\hline
\end{tabular}

\section{SHISTOSOMIASIS}

It is caused by S.japonicum, S.haematobium, S. mansoni, S. mekongi. The larvae enter inside the snail (intermediate host) before releasing into water. Snails laying egg condition depend on different climatic condition such as rainfall, water temperature, flow of water and duration of rainy and dry seasons. The most common climatic parameter, construction of dams led to increase in cases of shistosomiasis, discussed in literature. In Egypt and Iran, due to construction of dams and new canal system led to increase in snail populations, which subsequently led to increase in shistosomiasis cases in these areas $(21,22)$.

\section{Tissue Nematodes}

Filariasis is transmitted by Culex, Aedes and Anopheles mosquitoes, and caused by Wuchereria bancrofti. Enviornmental condition such as flooding and cropping of rice in Orient and stagnant water in India, provide favourable breeding place to mosquitoes resulted in increased in filiariais cases in those regions $(21,23)$.

Loiasis is transmitted by bite of Chrysops fly. They mostly breed in dense and swamp forest in Africa, however, deforestation decreases their prevalene. (24)

Onchocerciasis is transmitted by bite of simuliidae (black fly), most common in African regions. Climatic factor such as rainfall provide favourable breeding condition to blackfly (25).

\section{WATER Borne PARASITIC DiSEaSES}

The transmission of water borne parasitic diseases such as Giardiasis and Cryptosporidium are affected by climatic factors such as rainfall, temperature, livestock intensification e.t.c.(Table 2). 
Several outbreaks of Cryptosporidiasis and Giardiasis due to change in climatic factors are shown in number of studies (26-30).

Table 2. Effect of climatic change on water borne parasitic infections (26-30)

\begin{tabular}{|l|l|l|}
\hline S.No. & Climatic factors & Impact on pathogen \\
\hline 1. & Increase rainfall & $\begin{array}{l}\text { Increase flooding } \\
\text { Increase contamination of drinking water with septic tanks } \\
\text { Increase run off increases oocyst contamination of drinking water. } \\
\text { Increase contamination of vegetable crops with sewage effluent. }\end{array}$ \\
\hline 2. & Decrease rainfall & $\begin{array}{l}\text { Increase storage of water } \\
\text { Decrease run off } \\
\text { Increase contamination of ground water sorce }\end{array}$ \\
\hline 3. & Increase temperature & $\begin{array}{l}\text { Increase dessication } \\
\text { Decrease survival of oocyst }\end{array}$ \\
\hline 4. & $\begin{array}{l}\text { Intensification of domestic } \\
\text { livestock }\end{array}$ & $\begin{array}{l}\text { Increase contamination of water sources } \\
\text { Increase contamination of food sources } \\
\text { Increase pathogen reservoirs }\end{array}$ \\
\hline
\end{tabular}

\section{FUTURE PERSPECTIVE}

Climatic variability due to natural condition (Floods, Earth quake, Tsunami) or human interventions such as deforestration, urbanisation, water control projects, bodies of water in disrupted area, globilisation can singly or in combination can lead to ecological disturbances, survival of parasites, their spread and in turn incidence of parasitic infections. Therefore, improved surveillance and monitoring is needed so that one should make better use of early warning information to make early action towards epidemic preparedness due to ecological disturbances. The leaders of health sector must stand hand in hand with climate negotiators to confront climate change. Further, leaders from government, private sectors and civil society are encouraged to take action towards climatic change.

\section{REFERENCES}

[1] Tyssul Jones TW. Deforestation and epidemic malaria in the wet and intermediate zones of Ceylon. Ind J Malariolog 1951;5(1):135 \pm 61 .

[2] Sioli H. Amazonia: fundamentos da ecologia da maior regiao de forestas tropicais. Petropolis: Vozes Ltda, 1985.

[3] Marques AC. Human migration and the spread of malaria in Brazil. Parasitol Today 1987;3:166-70

[4] Southgate VR. Shistosomiasis in the Senegal River Basin: before and after the construction of dams at Diama Senegal and Manantali, Mali and future prospects. J Helminthol 1997;71(2):125 - 32.

[5] Fowler ME. Husbandry and disease of camelids. Rev Sci Technol 1996;15:155 - 69.

[6] Hunter DL. Tuberculosis in free-ranging, semi-ranging and captive cervids. Rev Sci Technol 1996;15:17181.

[7] Nizeyi JB, Mwebe R, Nanteza A, Cranfield MR, Kalema GRNN, Graczyk TK. Cryptosporidium sp. and Giardia sp. infections in mountain gorillas (Gorilla gorilla beringei) of the Bwindi Impenetrable National Park, Uganda. J Parasitol 1999;85(6):1084 -8.

[8] Geoecologia y desarollo Amazonico: estudio integrado en la zona de Iquitos. In: Kalliola R, Flores Paitan S, editors. Peru. Sulkava: Finnreklama Oy, 1998

[9] Washino RK, Wood BL. Application of remote sensing to arthropod vector surveillance and control. Am J Trop Med Hyg 1994;50(6 Suppl):134 -44.

[10] World Meteorological Organisation/United Nations Environment Programme. Scientific assessment of ozone depletion: 1994. Global Ozone Research and Monitoring Project Report No. 25. Geneva: World Meteorological Organisation, 1995

[11] Perciasepe R. Combined sewer overflows: where are we four years after adoption of the CSO control policy? Washington (DC): EPA Office of Wastewater Management, 1998.

[12] Rose JB, Simonds J. King County water quality assessment: assessment of public health impacts associated with pathogens and combined sewer overflows. Seattle, WA: Water and Land Resources Division, Department of Natural Resources, 1998

[13] Patz JA, Lindsay SW. New challenges, new tools: the impact of climate change on infectious diseases. Curr Opin Microbiol 1999;2:445 -51.

[14] Kilian AHD, Langi P, Talisuna A, Kabagambe G. Rainfall pattern El Nino and malaria in Uganda. Trans R Soc Trop Med Hyg 1999;93:22 - 23. 
[15] Downs WG, Pittendrigh CS. Bromeliade malaria in Trinidad. British West Indies. Am J Trop Med Hyg 1946;26:47- 66.

[16] Tadei WP, Dutary Thatcher B, Santos JMM, et al. Ecological observations on Anopheline vectors of malaria in the Brazilian Amazon.Am J Trop Med Hyg 1998;59(2):325 - 35.

[17] Ready PD, Lainson R, Shaw JJ. Leishmaniasis in Brazil: XX Prevalence of enzootic rodent leishmaniasis' (Leishmania Mexicana amazonensis), and apparent absence of 'pian bois' (Le. Braziliensis guyanensis), in plantations of introduced tree species and in other non-climax forests in eastern Amazonia. Trans R Soc Trop Med Hyg 1983;77(6):775 - 85.

[18] Warburg A, Montoya-Lerma J, Jaramillo C, Cruz-Ruiz AL, Ostrovska K. Leishmaniasis vector potential Lutzomyiaspp. In Colombian coffee plantation. Med Vet Ent 1990;5:9-16.

[19] Scorza JV, Castillo L, Rezzano S, Marquez M, Marquez C. El papel d cafeto en la endemicidad de la leishmaniasis cutanea en Venezuela.Bol Direcc Malar Saneam amb 1985;25:82 - 88.

[20] Zijlstra EE, Ali MA, el-Hassan AM, et al. Kala-azar in displaced people from southern Sudan: epidemiological, clinical and therapeutic findings. Trans R Soc Trop Med Hyg 1991;85(3):365-9.

[21] Jobin W. Ecological design and health impacts of large dams, canals, and irrigation systems. London: E\&F.N. Spon, 1999

[22] Amin M, Fenwick A, Teesdale C, McLaren M. The assessment of a 3 year snail control programme in the Gezira irrigated area Sudan. Ann Trop Med Hygiene Parasitol 1982;76:557 - 80

[23] Rajagopalan PK, Das PK, Paniker KN, Reuben R, Rao DR, Self LS, Lines JD. Environmental and water management for mosquito control. In: Curtis CF, editor. Appropriate technology in vector control. Boca Raton, FL: CRC Press, 1990. pp. $121-38$

[24] Duke BOL. Behavioral aspects of the life cycle of loa. In: Canning EU, Wright CA, editors. Behavioural aspects of parasitic transmission. Supplement No. 1 Zoological Journal of the Linnean Society 51. London: Academic Press, 1972. pp. 97- 107

[25] Nwoke BE, Onwuliri CO, Ufomadu GO. Onchocerciasis in Plateau State Nigeria: ecological background, local disease perception \& treatment; and vector/parasite dynamics. J Hyg Epidemol Microbiol Immunol 1992;36(2):153- 60.

[26] Hoxie NJ, Davis JP, Vergeront JM, Nashold RD, Blair KA. Cryptosporidiosis- associated mortality following a massive waterborne outbreak in Milwaukee Wisconsin. Am J Public Health 1997;87(12):2032 -5 .

[27] Mac Kenzie WR, Hoxie NJ, Proctor ME, et al. A massive outbreak in Milwaukee of cryptosporidium infection transmitted through the public water supply. N Engl J Med 1994;21:1 21;331(3):161-7.

[28] Kramer MH, Herwaldt BL, Craun GF, Calderon RL, Juranek DD. Surveillance for waterborne-disease outbreaks-United States 1993-1994. Mor Mortal Wkly Rep CDC Surveill Summ 1996;45(1):1- 33.

[29] Alterholt TB, LeChevallier MW, Norton WD, Rosen JS. Effect of rainfall on giardia and crypto. J Am Water Works Assoc 1998;90(9):66 - 80.

[30] Amahmid O, Asmama S, Bouhoum K. The effect of waste water reuse in irrigation on the contamination level of food crops by Giardia cysts and Ascaris eggs. Int J Food Microbiol 1999;49(1-2):19-26.

Citation: S. K. Agrawal, "Impact of Climatic Variation on Parasitic Infections - Short Review ", International Journal of Research studies in Microbiology and Biotechnology, vol. 3, no. 3, p. 5, 2017. http://dx.doi.org/10.20431/2454-9428.0303005

Copyright: (c) 2017 Authors. This is an open-access article distributed under the terms of the Creative Commons Attribution License, which permits unrestricted use, distribution, and reproduction in any medium, provided the original author and source are credited. 